\section{Interaction between Lymphocytes and Lecithin-cholesterol Vesicles*}

\section{GEORGE DRESDNER, ${ }^{a}$ ANDERS EHRENBERG, ${ }^{a}$ LENNART HAMMARSTRÖM and EDVARD SMITH ${ }^{b}$}

a Department of Biophysics, Stocholm University, S-106 91 Stockholm, Sweden and b Department of Immunobiology, Karolinska Institute, Wallenberg Laboratory, S-104 05 Stockholm, Sweden

The interaction between biological cells and lipid vesicles (liposomes) has been a subject of widespread investigation in the last years. ${ }^{1}$ The subject has acquired larger interest due to the possibility of locating in the interior and the membrane of the liposome various substances which later can be transferred to the cells. ${ }^{1-3}$ One aspect that has deserved special attention has been the study of the physicochemical and physiological mechanisms involved in this interaction. ${ }^{1,4}$ A cell system that has elicited particular attention due to the central role that it plays in immunological phenomena is the lymphocyte. ${ }^{5,6}$ We have been interested in studying both the mechanisms by which lecithin vesicles containing cholesterol are incorporated into lymphocytes and the effect of increased cholesterol content of the cells on their activation. We report in this communication results from our investigations on the first of the forementioned problems, obtained mainly by using spin label techniques.

Vesicles of lecithin (L) and lecithin-cholesterol (LC) spin labeled with 5-doxyl-stearic acid** and 3-doxylcholestane, respectively, were prepared by sonication. The ESR (electron spin resonance) spectrum of the vesicles showed a linear increase of the hyperfine splitting $\left(2 \mathrm{~T}_{\|}{ }^{\prime}\right)$ with their cholesterol molar fraction ( 0 to 0.56$)$. The form of the ESR spectrum of the vesicles changed also with the concentration of spin label used in their preparation. Mixtures of $B$ and $T$ lymphocytes $\left(10^{7}\right.$ cells $\left./ \mathrm{ml}\right)$, obtained from spleen of male A.CA mice, were incubated at 23 or $37^{\circ} \mathrm{C}$ with various amounts of $L$ and $L C$ (molar ratio $1: 2$ ) vesicles for different periods of time $(5 \mathrm{~min}$ to $24 \mathrm{~h})$ and sedimented. Phosphate and cholesterol contents and the ESR spectrum were measured on cells and supernatants.

It was found, as detected by the ESR-signal intensity of the samples, that the vesicles bound to the cells already after 5 min incubation. Maximal binding was reached after $15 \mathrm{~min}$ incubation, followed by a decline of $20 \%$ after

* Communication at the Meeting of the Swedish Biochemical Society in Gothenburg, 7-8th June, 1979.

** doxyl=2,2-dimethyl- $N$-oxyl-oxazolidine.
$3 \mathrm{~h}$ incubation. The cholesterol content of the cells showed a parallel increase to that of the ESR-signal intensity. Vesicle binding to the cells was dependent on the vesicle-cell ratio and reached a plateau value at $1 \times 10^{-8} \mu \mathrm{mol}$ vesicle phosphorus/cell. The ESR-signal intensity of the cell-bound spin label decayed according to a first order kinetics. It was temperature dependent with an activation energy of about $2 \mathrm{kcal} / \mathrm{mol}$ spin label. Decay of the ESR-signal intensity was observed even at the shortest incubation periods. The addition of potassium ferricyanide, sodium azide or $p$-hydroxy-mercuribenzoate to the cells after incubation did not modify the rate of the reaction. These results suggest that the decay of the ESR-signal intensity was due to an intracellular enzymatic reaction near the cell membrane. The changes that occurred in the ESR spectrum of the lymphocyte-vesicle complex, using during incubation vesicles containing various amounts of spin label, suggested that the label incorporated into the cell mem. brane but vesicle incorporation via endocytosis also occurred.

1. Pagano, R. E., Sandra, A. and Takeichi, M. Ann. N. Y. Acad. Sci. 308 (1978) 185.

2. Gregoriadis, G. N. Engl. J. Med. 295 (1976) 704.

3. Gregoriadis, G. N. Engl. J. Med. 295 (1976) 765.

4. Poste, G. and Papahadjopoulos, D. Ann. N. Y. Acad. Sci. 308 (1978) 164.

5. Blumenthal, R., Weinstein, J. N., Sharrow, S. O. and Henkart, P. Proc. Natl. Acad. Sci. U.S.A. 74 (1977) 5603.

6. Huang, L., Ozato, K. and Pagano, R. E. Memb. Biochem. 1 (1978) 1.

Received May 29, 1979. 